\title{
LEXICAL AND SEMANTIC FEATURES OF GEOLOGY TERMS IN ENGLISH
}

\section{Rohach L. V.}

\section{INTRODUCTION}

Terminology has always been the object of linguistic investigation. It can be explained by the fact that terms are always used by the speakers of many languages, they can be found in manuals of many spheres of human activities. Many terms have become lexical units of common language, because of the extreme development of modern science. Terminology is a separate subsystem of lexicology. The main tendencies of lexicology of national language are reflected in terminology.

Semantics is central in the study of communication. As communication becomes more and more a crucial factor in social organization, the need to understand it becomes more and more pressing. Nowadays, undeniable is the statement about the primacy of linguistic content over form, the primacy of the lexical basis in the word and the possibility of applying semantic approach to the formalized study of all levels of language ${ }^{1}$.

The importance of the present research is dictated by the need of investigating English terminological system of geology with application of the methodology of formalized analysis of lexical semantics, that in our research presupposes distinguishing the meanings of lexical units in common language and terminological system, the study of correlation between different terminological systems and different semantic phenomena of terminology.

The object of the research is 74 English terms of geology with the explanation of their special and common meanings, 77 semes that were singled out from the meanings of the English lexical units. The subject of the research is detecting the semantic characteristics of the English lexical units being the members of terminological system of geology and a part of common language lexical layer. In our investigation, we present the characteristics of these meanings by means of describing the matrix, constructed according to the principle of rank arrangement of the components of meanings.

${ }^{1}$ Сорока Т.В. Семантика найбільш багатозначних англійських аксіономерів // Сучасні дослідження з іноземної філології. Вип 12. 2014. С. 189. 
The structure and system of literary language are most naturally and extensively represented by dictionaries, where the content of lexical units is covered in a comprehensive way. Taking into account that "in the dictionaries modern linguistics receives the most reliable and polished material for formalized analysis of lexical semantics" 2 , we have used English explanatory dictionaries as a basis for the research. The specificity of terminological studies prompted the necessity of investigation of terminological dictionaries, which helped to define the peculiarities of the analyzed lexical units and state the characteristics of their dictionary representation. We strongly support the statement that "terminography as an integrative discipline about the practice and theory of special terminological dictionaries compilation is a branch located at the intersection of lexicography, terminology, and a specific professional discipline” ${ }^{3}$.

Semantic analysis of geology terms is performed on the basis of lexicographic sources, such as explanatory dictionary Longman Dictionary of Contemporary English and terminological dictionaries McGraw-Hill Dictionary of Earth Science and McGraw-Hill Dictionary of Geology and Mineralogy.

Relying on dictionary definition in semantic studies has its obvious advantages. They are as follows: 1) when paraphrasing and semantically expanding a dictionary entry none of the components of definitions are excluded; 2) the methodology provides the opportunity to recognize the identities and differences of the structures of lexical units' meanings based on the identities and differences of their periphrases; 3) it becomes possible to operate a great number of lexical units, practically the whole dictionary.

\section{Componential analysis as a method of semantic study of lexical units of different structure}

The phenomenon of polysemy proved to be extremely important in our research as it is the basis of semantic structure of the majority of lexical units under analysis. In this study we treat polysemy as both a common language phenomenon and a terminological one.

Most English words are polysemantic, i.e. are characterized by more than one lexical meaning or lexico-semantic variants depending on the context of their usage. In scientific literature polysemy is viewed as "the existence in a word of several interconnected meanings that have one

2 Пещак М.М. Специфіка формальних ознак лексикографічної обробки слова // Формалізовані основи семантичної класифікації лексики. - Київ: Наукова думка, 1982. С. 10.

${ }^{3}$ Іваницький Р.В. Лексикографічні аспекти нормалізації термінів (на матеріалі німецьких, англійських, українських та російських термінологічних одиниць). - Львів, 1995. С. 6. 
or more common semantic components" ${ }^{4}$. Y.Kuznetsova defines a polysemantic word as "a cluster of several semantic variants of meaning related to one lexeme" 5 . These variants or separate meanings form a semantic word paradigm, are semantically connected and can be realized in different typical contexts.

Any polysemantic word is characterized by the system of meanings that develops gradually, mostly over the centuries, as more and more new meanings are added to old ones, or some of them become extinct. Thus, the complicated processes of polysemy development involve both the emergence of new meanings and the loss of old ones. Yet, the general tendency with English vocabulary at the modern stage of its history is to increase the total number of its meanings and in this way to provide for a quantitative and qualitative growth of expressive resources of the language.

Polysemy is inherent in the very nature of words and concepts as every object and every notion has many features and a concept reflected in a word always represents generalization of several features of the object. Some of such features or components of meaning are common with other objects. Hence the possibility of using the same name in secondary nomination for objects possessing common features which are sometimes only implied in the original meaning. A word when acquiring new meaning or meanings may also retain, and most often it does retain the previous meaning. The semantic structure of a word should be investigated at both levels: 1) of different meanings; 2) of semantic components within each separate meaning. For a monosemantic word (word characterized by one meaning) the first level is naturally excluded. Semantic structure of the words - is the unity of all its meanings: grammatical forms and each individual meaning of polysemantic words ${ }^{6}$.

Polysemy in our research is viewed as the phenomenon when a word has more than one meaning that are characterized by different connections. In this respect words are not isolated in the language system but are interrelated with other semantic groups of words. In the course of time meanings of lexical units acquire different shades and even change, though retaining a certain relationship.

Modern semantics treats a separate word meaning as a complex entity having its own structure. Elaboration of this idea in practical aspect led to the emergence of methodology of componential analysis, which is widely applied in the investigations dealing with lexical semantics.

${ }^{4}$ Харитончик 3.А. Лексикология английского языка. - Минск: Вышейшая школа, 1992. C. 48.

${ }^{5}$ Кузнецова Е.В.Лексикология русского языка. - М.: Высшая школа, 1989. С. 101.

${ }^{6}$ Cruise D.A. Monosemy vs. polysemy: Linguistics. - Cambridge, 1992. P. 256. 
As an independent method in linguistics componential analysis appeared in the late 50ies of the 20 century. The term itself belongs to W. Goodenough. This method is based on defining differential meaning components for the opposition of the words, which have the common semantic part ${ }^{7}$.

Componential analysis is particularly applicable to distinguish the meanings of lexemes that are semantically related or in the same semantic domain. It is based on the presumption that the meaning of a word is composed of semantic components. So the essential features that form the meaning are elementary units on semantic level. By componential analysis, it is possible to state the smallest indivisible units of lexis or minimal components $^{8}$. It is often seen as a process of breaking down the sense of a word into its minimal distinctive features; that is, into components which contrast with other components. It refers to the description of the meaning of words through structured sets of semantic features, which are given as "present”, "absent”, or "indifferent with reference to feature"”.

According to different authors minimal semantic units, that are the basis of componential analysis, are called semantic components, semantic features, seme, plereme, noema, semantic units, and so on. The components of meaning are viewed in componential analysis as atomic concepts. The lexical unit, seen as an independent entity, is not put under a separate analysis, but in its possible linguistic paradigmatic and syntagmatic links ${ }^{10}$. Componential analysis results in the selection of semes that are a part of words' lexical meanings being rigidly organized structures. A seme is a minimal unit of sense, an atom of lexical semantics distinguished on the basis of oppositions by method of componential analysis. A seme is not expressed in a word in any material unit but it's revealed and singled out through interrelations of the word with other words on a paradigmatic and syntagmatic levels.

In our investigation we understand a seme as a semantic microcomponent which reflects the specific features of the notion represented by the word. Each seme as a microcomponent of meaning is composed of two principal parts (components) - the semantic feature and seme specifier. The seme specifier is the part of the seme which specifies the particular semantic feature.

${ }^{7}$ Goodenough W.H. Componential Analysis and the Study of Meaning. Language 32(1), 1956. P. 210.

${ }^{8}$ Aitchison Jane. Linguistics. - London: Hodder and Stoughton, 2003. P. 92.

${ }^{9}$ Saeed, John. Semantics. - United Kingdom: Wiley Blackwell, 2009. P. 260.

${ }^{10}$ Enesi M. Strati K Contemporary methods of semantic studies and their impact in translation // Interdisiplinary Journal of Research and Development, Vol. 4. № 3. 2017. P. 121-122. 
There are two types of componential analysis: minimal and full. Minimal componential analysis of a group of words is a simple method that defines divergences in the semantics of words. As a rule, it is used in such cases when it is necessary to distinguish the meanings of synonyms or groups of semantically close words. The method is being implemented until each word has its own set of semes. The goal of full componential analysis is not the division of word meanings, as it is characteristic of minimal componential analysis, but the full defining of the seme structure of a sememe. Full componential analysis is carried out by means of dictionary definitions with attraction of the whole lexico-semantic group of words, to which an investigated unit belongs. In full componential analysis all the units of the given lexico-semantic group fall under analysis.

The linguists have different viewpoints on the very essence of componential analysis. I.V. Arnold states that componential analysis is a procedure when the meaning of a great number of lexico-semantic variants is described by means of limited inventory of semantic units ${ }^{11}$. Componential analysis is also characterized as a method of investigation the meaningful side of lexical units of language that is elaborated within the framework of structural semantics and aims at decomposing meanings into minimal semantic components ${ }^{12}$.

The essence and purpose of method of componential analysis in our research lies in the fact that meanings of terms are segmented into features by which some lexical units are distinguished from each other, the other, on the contrary, are grouped or aggregated. We treat componential analysis as one of the main ways of revealing of the inner structure of the language especially of its lexical composition.

A seme is viewed as the minimum unit of meaning, which is not selfsufficient, because it cannot be realized independently, but only within another semantic size, inside sememe (which appears as an inclusive unit as opposed to seme, as an 'included' unit). According to the conception, sememe is formed by a group of semantic features ${ }^{13}$.

The problem of investigating the mechanisms of term formation and the links between the seme structure and the common semantic component, studying the influence of these multilevel relationships on the processes of functioning and evolution of the term in different terminological systems occupies a significant place in modern semantic

\footnotetext{
${ }^{11}$ Арнольд И.В. Семантическая структура слова в современном английском языке и методика ее исследования. - Л.: Просвещение, 1966. С. 80.

${ }^{12}$ Leech G. Semantics. - London: Penguin Books, 1975. P. 98.

${ }^{13}$ Enesi M. Strati K Contemporary methods of semantic studies and their impact in translation // Interdisiplinary Journal of Research and Development, Vol. 4, no. 3, 2017. P. 121-122.
} 
research $^{14}$. In this respect it is relevant that the study of semantics of the English geology terms as both common language and terminological units revealed that the meanings of terms are characterized by certain semantic features testifying to obvious dissimilarity of some terms, and, on the contrary, the similarity of other, being thus united into groups.

A word, that in our research is both a common language lexical unit and a term, presents not simply the totality of knowledge, but forms a generalized semantic image. All the meanings taken together, the relationships between them and the words associated with them form a certain semantic space inside which one can distinguish separate semantic centres.

We view semantic space as a common semantic basis, which "in combination with the acoustic-graphic image provides it with integrity, economy of storage in memory and dynamism in communication”" Semantic space of English geology terminological lexis is a continuous and heterogeneous phenomenon. This heterogeneity reveals the potential for the emergence of new semantic centres due to contraction or distancing at any place of this space. As a result of this process, new terminological vocabulary arises, which eventually becomes a lexical-semantic variant of the semantic structure of the word.

\section{Lexical peculiarities of geology terms in the English language}

English terms of geology that constitute research language material were selected from terminological dictionaries of geology and their common language semantics was observed in the explanatory dictionaries. Linguistic method of componential analysis was applied to examine the geology terms' common language and special semantics. In order to achieve this aim we singed out semes from commonly used and terminological meanings. Methodology of formalized analysis of lexical units' semantics was applied to investigate semantic peculiarities of English terms of geology. Matrix of semantic space of English geological terms was constructed. It presents the terms, arranged in horizontal lines and semes, set in vertical lines order. On the crossing of the rows and columns, we indicate the existence of seme realizations in the investigated meanings. The ordering of the whole seme stock of the investigated material was carried out on the basis of quantitative criterion. The most widely occurring semes are placed at the beginning of the table, the semes with an average degree of occurrence and monofunctional semes are found

\footnotetext{
${ }^{14}$ Алієва О. Спільний інваріантний компонент: формування семантичної та концептуальної структури терміна // Сучасні дослідження з іноземної філології. Вип. 13. 2015. С. 269.

${ }_{15}$ Фабіан М.П. Етикетна лексика в українській, англійській та угорській мовах. Ужгород: Інформаційно-видавниче агентство «IBA», 1998. С. 123. 110
} 
at the end of the arranged list. The investigated English terms of geology are placed in the decreasing order - from the most polysemantic lexical unit to the monosemantic ones. According to the matrix three groups of terms can be distinguished: lexical units with wide semantics, lexical units with average degree of semantics and lexical units with narrow semantics (monosemantic).

The group of lexical units characterized by the highest degree of polysemy consists of the following terms bank, bar, bed, contact, aspect, ball, basin, depression, floor, consolidation, earth, face, fan, gap. Semantic structure of these lexical units comprise from 9 to 5 meanings in the dictionary entry. To show the difference between common language and special semantics of the first group of geology terminological units we have selected the following examples.

Common language word contact denotes communication with a person, organization, country; when two people or things touch each other; when you meet someone or experience a particular kind of thing; a person you know who may be able to help or advise you; an electrical part that completes a circuit when it touches another part; contact lens ${ }^{16}$. As a terminological unit contact is used in the meaning the surface between two different kinds of rocks ${ }^{17}$. The common semantic component of these meanings can be defined as somebody or something touching. It is quite obvious that the term contact was formed by means of semantic way of term formation or terminologization.

Common language meanings of the word basin are as follows: a round container attached to the wall in a bathroom, where you wash your hands and face; a large bowl-shaped container for liquids or food; the amount of liquid that a basin can contain; an area of land that is lower at the centre than at the edges; a place where the Earth's surface is lower than in other areas. Terminological dictionary of geology defines the term basin as a polysemantic one meaning: a low-lying area, wholly or largely surrounded by higher land, that varies from a small, nearly enclosed valley to an extensive, mountain-rimmed depression; an entire area drained by a given stream and its tributaries; an area in which the rock strata are inclined downward from all sides toward the center; an area in which sediments accumulate ${ }^{18}$. In oceanography basin is understood as deep portion of sea surrounded by shallower regions ${ }^{19}$. The meanings included into explanatory dictionary implicitly define this word as a term of geology.

\footnotetext{
${ }^{16}$ Longman Dictionary of Contemporary English. - Longman Group Ltd, 2000.

${ }^{17}$ McGraw-Hill Dictionary of Earth Science [Electronic resource]: yunus.hacettepe.edu.tr.

${ }^{18}$ Longman Dictionary of Contemporary English. - Longman Group Ltd, 2000.

${ }^{19}$ McGraw-Hill Dictionary of Earth Science [Electronic resource]: yunus.hacettepe.edu.tr.
} 
Depression in common language is used in the following meanings a medical condition that makes you very unhappy and anxious and often prevents you from living a normal life; a long period during which there is very little business activity and a lot of people did not have jobs; a part of a surface that is lower than the other parts; a mass of air under low pressure, that usually causes rain ${ }^{20}$. Geological term depression is fixed in the dictionary as a hollow of any size on a plain surface having no natural outlet for surface drainage; a structurally low area in the crust of the earth. In meteorology it is an area of low pressure; usually applied to a certain stage in the development of a tropical cyclone, to migratory lows and troughs, and to upper-level lows and troughs that are only weakly developed $^{21}$. The seme part of a surface is common in the semantic structure of depression as a common language word and a term of geology, what testifies to the semantic way of term formation in this case.

Consolidation is a common language lexical unit which denotes unity of some forces and position of power or success. In business the term consolidation is used in the meanings: 1) when companies combine in takeovers resulting in fewer businesses; 2) when organizations or departments become joined together; 3) when a company's position of power or success is made stronger and more likely to continue ${ }^{22}$. As a term of geology consolidation means 1) processes by which loose, soft, or liquid earth become coherent and firm; 2) adjustment of a saturated soil in response to increased load; involves squeezing of water from the pores and a decrease in void ratio ${ }^{23}$.

The analysis of the first group of lexical units of our language material shows that the semantic structure of the English terms of geology is rather broad containing several meanings. The conclusion can be made that terminological meanings of these words are derived from the common language ones on the basis of common semantic feature. Thus, terms of geology of this group of our material were formed by means of terminologization. A distinctive feature of geological terms of this group is that the majority of them are polysemantic terminological units containing at least two special meanings in their semantic structure. Semantics of lexical units of this group is also characterized by strong scientific character as a lot of geology terms of this group are the terms of other branches of human activity, especially of such related spheres as oceanography, meteorology and hydrology. The performed formalized

\footnotetext{
${ }^{20}$ Longman Dictionary of Contemporary English. - Longman Group Ltd, 2000.

${ }^{21}$ McGraw-Hill Dictionary of Earth Science [Electronic resource]: yunus.hacettepe.edu.tr.

${ }^{22}$ Longman Dictionary of Contemporary English. - Longman Group Ltd, 2000.

${ }^{23}$ McGraw-Hill Dictionary of Earth Science [Electronic resource]: yunus.hacettepe.edu.tr.
} 
analysis allows us to state that in the semantic space of this group of English geology terms the majority of meanings are conveyed by multifunctional semes.

The second group of polysemantic lexemes in our language material is the most numerous one comprising 35 units. The second group represents the English geology terminological units with average degree of polysemy. The common language semantic structure of these words contain from 4 to 2 meanings. It consists of the following terms: abstraction, accretion, age, basement, bend, degradation, assimilation, axis, backbone, erosion, event, finger, descendant, advance, deflation, bench, cap rock, cay, correlation, arm, closure, chimney rock, clast, clay, annual layer, episode, accumulation, basset, declivity, berm, blind etc.

The analysis showed that lexical unit accretion is not used in common language meanings being characterized by two special meanings in geology: 1) gradual buildup of land on a shore due to wave action, tides, currents, airborne material, or alluvial deposits; 2) the process whereby stones or other inorganic masses add to their bulk by adding particles to their surfaces; and one special meaning in meteorology: the growth of a precipitation particle by the collision of a frozen particle (ice crystal or snowflake) with a supercooled liquid droplet which freezes upon contact ${ }^{24}$.

Lexical unit assimilation in the explanatory dictionary is fixed in the following meanings: 1) the process of understanding and using new ideas; 2) politics the process of becoming an accepted part of a country or group; 3) linguistics a phonetical process, in which two phonemes adjacent or very near to each other acquire common characteristics or become identical ${ }^{25}$. In special geological dictionary assimilation denotes incorporation of solid or fluid material that was originally in the rock wall into a magma ${ }^{26}$. It is clear, that this word has a strong scientific character being the term of several sciences.

The term of geology backbone is characterized by the following common language meanings: 1) the row of connected bones that go down the middle of your back; 2) courage and determination ${ }^{27}$. In geology the term backbone originated from the common language meaning of the row of connected bones that go down the middle of your back and denotes 1) a ridge forming the principal axis of a mountain; and 2) the principal

\footnotetext{
${ }^{24}$ McGraw-Hill Dictionary of Earth Science [Electronic resource]: yunus.hacettepe.edu.tr.

${ }^{25}$ Longman Dictionary of Contemporary English. - Longman Group Ltd, 2000.

${ }^{26}$ McGraw-Hill Dictionary of Earth Science [Electronic resource]: yunus.hacettepe.edu.tr.

${ }^{27}$ Longman Dictionary of Contemporary English. - Longman Group Ltd, 2000.
} 
mountain ridge, range, or system of a region ${ }^{28}$. As far as this term has two meanings in the sphere of geology we would suggest adding these terminological meanings to common language ones marking them by the lexicographical note geology.

Lexical unit finger is fixed in terminological dictionary in the following meanings: 1) one of the four long thin parts on your hand, not including your thumb; 2) the part of a glove that covers your finger; 3) anything that is long and thin, like the shape of a finger, especially a piece of land, an area of water, or a piece of food ${ }^{29}$. Terminological meaning of the lexical unit finger originated from the capacity of fingers to move forward irregularly (the tendency for gas which is displacing liquid hydrocarbons in a heterogeneous reservoir rock system to move forward irregularly (in fingers), rather than on a uniform front ${ }^{30}$ ). We consider the geology term finger to be formed by semantic way of term formation on the basis of similarity of functions of these concepts.

Bench as a common language lexical unit has the following meanings: 1) a long seat for two or more people, especially outdoors; 2) a long heavy table used for working on with tools or equipment ${ }^{31}$. In our opinion these meanings were taken as a basis when the geology term bench was formed as far as the terminological meaning a terrace of level earth or rock that is raised and narrow and that breaks the continuity of a declivity has a strong resemblance to the common language ones.

In common language the word arm is used in the following meanings: one of the two long parts of your body between your shoulders and your hands; the part of a chair, sofa ${ }^{32}$. The term of geology arm was formed on the basis of similarity of the form of these two concepts as in geology arm is a ridge or a spur that extends from a mountain. In oceanography it is a long, narrow inlet of water extending from another body of water ${ }^{33}$.

The most vivid features of geological terms of the second group of average degree of polysemy are as follows:

1) terminological polysemy of the majority of terms of geology in this group;

2) the phenomenon when terminological meaning in geology implicitly or explicitly resembles the common language one, thus we can conclude that such term was formed by semantic way of term formation;

\footnotetext{
${ }^{28}$ McGraw-Hill Dictionary of Earth Science [Electronic resource]: yunus.hacettepe.edu.tr.

${ }^{29}$ McGraw-Hill Dictionary of Earth Science [Electronic resource]: yunus.hacettepe.edu.tr.

${ }^{30}$ Ibid.

${ }^{31}$ Longman Dictionary of Contemporary English. - Longman Group Ltd, 2000.

32 Ibid.

${ }^{33}$ McGraw-Hill Dictionary of Earth Science [Electronic resource]: yunus.hacettepe.edu.tr.
} 
3) the possibility of introducing terminological meaning in geology into the explanatory dictionary and labeling it by the lexicographical note geology;

4) in the semantic space many terms of this group are united by the semantic feature related spheres designating intersystem terminological polysemy in such related earth sciences as oceanography, hydrology and meteorology.

One and the same term can be used in several terminological systems. Simultaneous usage of one term in mathematics, chemistry, medicine, biology, jurisprudence, logic, physics, philosophy, etc. in our opinion is the display of intersystem terminological polysemy. This can be accounted for the similarity of semantic processes in different spheres of human activity.

The third group of lexical units in our material contains monosemantic terms of geology having narrow special semantics. The examples of monosemantic lexical units of our material are as follows: base level - that critical plane of erosion and deposition represented by river level on continents and by wave or current base in the sea; cavern - an underground chamber or series of chambers of indefinite extent carved out by rock springs in limestone; cluse - a narrow gorge, trench, or water gap with steep sides that cuts transversely through an otherwise continuous ridge; cluse - a narrow gorge, trench, or water gap with steep sides that cuts transversely through an otherwise continuous ridge; denudation general wearing away of the land; laying bare of subjacent lands.

The peculiarity of this group of words is that some of the terms are not registered in the explanatory dictionary as they don't have common language meanings at all. Some of the terms are fixed in this type of lexicographical source being implicitly defined as the terms of geology but not labeled as the ones referring to this sphere.

\section{Seme Analysis of English Terms of Geology}

The matrix constructed on the basis of lexical and seme composition of the English geology terms represents the structure of semantic space of geology terminology in the system of common language. From the meanings of 74 geology terms 77 semes were selected. On the basis of quantitative criterion the semes were divided into three main groups: polyfunctional semes, semes of average degree of occurrence and monofunctional semes.

The analysis showed that the following semes are polyfunctional in our material: land, ground; part of, portion; rock; process, action; expressions; science; close sphere; something; period, time; area; ridge; 
person. These semes are the components of meanings of from 13 to 5 geology terms.

The seme land, ground unites the meanings of 13 words in our material: bank, bed, floor, consolidation, earth, accretion, degradation, erosion, bench, denundation, geanticline, geocosmogony, macropore. In the majority of meanings this seme represents terminological meaning in the sphere of geology. For example: accretion - gradual buildup of land on a shore due to wave action, tides, currents, airborne material, or alluvial deposits; degradation - the wearing down of the land surface by processes of erosion and weathering; erosion - the wearing away of the land, chiefly by rain and running water ${ }^{34}$. In the semantic structure of the terms bank and earth the seme land, ground unites terminological and common language meanings.

The seme part, portion was singled out from the meanings of 12 lexical units: bar, contact, aspect, basin, floor, earth, face, abstraction, axis, arm, clast, berm. In the semantics of 5 words this seme bears terminological character. For example: clast - an individual grain, portion, fragment, or constituent of detrital sediment or sedimentary rock produced by physical breakdown of a larger mass; berm - a horizontal portion of a beach or backshore formed by deposit of material as a result of wave action. Semantics of the majority of lexical units united by this seme is of common language character. For example: aspect - one part of a situation, idea, plan etc that has many parts; arm - one of the two long parts of your body between your shoulders and your hands.

The seme rock in our material unites terminological semantics of the following words: bar, bed basin, floor, basement, assimilation, cap rock, clast, ablation moraine, basset, allochthon. For example: ablation moraine - a layer of rock particles overlying ice in the ablation of a glacier; assimilation - incorporation of solid or fluid material that was originally in the rock wall into a magma; basin - an area in which the rock strata are inclined downward from all sides toward the center ${ }^{35}$.

The semantic feature of process, action was singled out from the semantics of 11 lexical units: abstraction, accretion, bend, degradation, assimilation, erosion, deflation, correlation, abration, accumulation, icerafting. In the majority of cases this seme bears terminological character. For example: accretion - the process whereby stones or other inorganic masses add to their bulk by adding particles to their surfaces; deflation the sweeping erosive action of the wind over the ground; ice-rafting - the

\footnotetext{
${ }^{34}$ McGraw-Hill Dictionary of Earth Science [Electronic resource]: yunus.hacettepe.edu.tr.

${ }^{35}$ Ibid.
} 
process of transporting of rock and other minerals, of all sizes, on or within icebergs, ice floes, river drift, or other forms of floating ice. In the semantic structure of the words assimilation and erosion the seme process, action has both terminological and common language character. For example, terminological meaning of the word erosion is - the process by which rock or soil is gradually destroyed by wind, rain, or the sea. Common language meaning of this lexical unit is - the process by which something is gradually reduced or destroyed.

Semantic feature of scientific character of the words under analysis was marked in our language material by two semes science and close spheres as far as geology is closely connected with such earth sciences as meteorology, hydrology and oceanography. Thus, the seme science in our material denotes the meanings of words in distant sciences such as politics, linguistics, economics ect. and the seme close spheres in such sciences as meteorology, hydrology and oceanography. The seme science unites semantics of the following terms: bank, aspect, consolidation, earth, assimilation, axis, deflation, dendrochronology. For example: aspect linguistics the form of a verb in grammar that shows whether an action is continuing, or happens always, again and again, or once; bank economics a business that keeps and lends money and provides other financial services; deflation - economics a reduction in the amount of money in a country's economy, so that prices fall or stop rising. The semantic feature of close spheres unites semantics of the following terms: bank, bed, basin, depression, accretion, arm, abration. For example: depression in meteorology is an area of low pressure; bank in oceanography is a relatively flat-topped raised portion of the sea floor occurring at shallow depth and characteristically on the continental shelf or near an island.

The seme ridge is a purely terminological one in our language material denoting special meaning in geology. The following terms are united by this semantic feature: bank, bar, ball, backbone, arm. For example: bar any of the various submerged or partially submerged ridges, banks, or mounds of sand, gravel, or other unconsolidated sediment built up by waves or currents within stream channels, at estuary mouths, and along coasts; ball - a low sand ridge, underwater by high tide, which extends generally parallel with the shoreline; usually separated by an intervening trough from the beach; arm - a ridge or a spur that extends from a mountain $^{36}$.

\footnotetext{
${ }^{36}$ McGraw-Hill Dictionary of Earth Science [Electronic resource]: yunus.hacettepe.edu.tr.
} 
The second group of semantic components in our material are the semes of average degree of occurrence. This group comprises 24 semes. We have singled them out of the meanings of four, three and two lexical units. They are as follows: amount of, quantity; place, position; surface; deposit; movement; deviation, difference; money; mass; body; material; state of, condition; layer; line, curve; mountain, slope; production; feature; ash; furniture; sand; reef, cliff; distance, touch; base; experience.

The seme amount of, quantity unites the meanings of 4 lexical units: bank, age, accumulation, abundance. In the semantic structure of accumulation and abundance this seme bears both common language and terminological character. For example: accumulation in terminology is the quantity of snow or other solid form of water added to a glacier or snowfield, such as by precipitation, wind drift, or avalanches and in common language the amount of something that collects or is collected over time. The term of geology abundance is explained as the relative amount of a given element among other elements and as a common language word - a large quantity of something.

The semes sport and body unite the following terms in the semantic space of geology terms: sport - bar, ball, event; body - bank, floor, cap rock. The characteristic feature of semantics of these terms is that sport in the meanings of all the terms is a common language feature whereas body - terminological one. For example: event - one of the races or competitions that are part of a large sports competition; ball - any game or sport played with a ball, especially baseball or basketball; cap rock an impervious body of anhydrite and gypsum in a salt dome; floor a horizontal, flat ore body.

The seme layer unites the following terms in the semantic space of geology terms: basement, annual layer. The seme line, curve unites terminological meanings of the words bend and axis. The semantics of these terms is located nearby in the semantic space of English geology terms. For example: annual layer - a sedimentary layer deposited, or presumed to have been deposited, during the course of a year; a line where a folded bed has maximum curvature; bend - a curve or turn occurring in a stream course, bed, or channel which has not yet become a meander; axis - a line where a folded bed has maximum curvature ${ }^{37}$. As we can see, these semes bear a purely terminological character in the semantic space of geology terms.

The semes of the third group unite the monofunctional semantic elements in our language material. This group contains 34 monofunctional

\footnotetext{
${ }^{37}$ McGraw-Hill Dictionary of Earth Science [Electronic resource]: yunus.hacettepe.edu.tr.
} 
semes. In our study they were detected in only one lexicographic explanation. They are as follows: drift; form; idea; name; sediment; direction; water; colour; appearance; erosion; subdivision; container; dog; elevation; seat; terrace; shelter, covering; flower; bed; matter; courage; island; chamber; column; fraction; end; gap; department; progress; communication; determination; connection; depression; disappearance. The majority of these semes are of terminological character.

The terms that contain the abovementioned semes in their semantic structure have no connections with other words in our material and are located separately in the semantic space.

The results of the performed semantic analysis are presented in the constructed matrix of semantic space of geology terms in the English languages. The matrix illustrates the semantic structure of geological terminology in English on the background of common language. The first part of the matrix is characterized by dense localization of semes. In the left upper part the realization of frequently used semes and lexical units with wide sematics is presented. This testifies to their significant semantic value in the semantic space of language. In this place of the matrix one can vividly see that the special semantics of English geology terms in many cases coincides with that of common vocabulary one, thus the concretization is needed for their identification. The left lower part of the matrix presents lexical units with average and narrow degree of semantics and correspondingly semes with average degree of occurrence and monofunctional ones. In the right part of the matrix we can observe relatively small number of seme realizations which are of both terminological and common language character.

\section{CONCLUSIONS}

The research is aimed at determining semantic peculiarities of the English terminology of geology in its different connections, in particular specific terminological and common language ones. The achievement of this aim preconditioned the application of componential analysis and the methodology of formalized analysis of lexical semantics of the investigated terminological units. The semantics of the geology terms was performed on the basis of terminological and explanatory dictionaries.

The construction of the matrix of semantic space of geology terms allowed us to divide terms into three groups according to the degree of their semantics: lexical units with the highest degree of polysemy, lexical units characterized by the average degree of polysemy and monosemantic terms. The first group of our material is not numerous, but the elements forming it have rather broad semantics containing a lot of meanings. 
Terminological meanings of this group in their majority are derived from the common language ones, thus the English geological terms of this group were formed by means of terminologization. The most vivid features of geological terms of the group of average degree of polysemy are as follows: terminological polysemy of the terms; the possibility of introducing terminological meaning in geology into the explanatory dictionary and labeling it by the lexicographical note geology; in the semantic space terms are united by the semantic feature related spheres designating intersystem terminological polysemy. The third group of lexical units in our material consists of monosemantic terms of geology having narrow special semantics. The peculiarity of this group of words is that some of the terms are registered in the explanatory dictionary being implicitly defined as the terms of geology but not labeled as the ones referring to this sphere.

The seme analysis of the language material enabled us to classify semes according to the quantitative parameter. We distinguish polyfunctional semes, semes with the average degree of occurrence and monofunctional. The group of polyfunctional semes occupies the first place in the matrix. The analysis shows that all the semes of this group have terminological character, only in some instances their terminological and common language functions coincide. The second and the third groups of our language material comprise the semes that have both terminological and common language character.

The results of the performed semantic analysis are presented in the matrix of semantic space of the English terms of geology that illustrates the semantic structure of geological terminology in English on the background of common language. Dense location of seme realizations in the left upper part of the matrix testifies to their significant value in the semantic space of language; concretization is needed for the identification of terminological semantics. The left lower part of the matrix presents lexical units with average and narrow degree of semantics displaying isolation in the semantic space.

The formalized research of English geology terms' semantics enabled us to define the main features of the semantic structure of these lexical units as the elements of terminological system and common language system and revealed the possibilities of their further semantic study.

\section{SUMMARY}

The present paper deals with the study of semantic features of the English terminology of geology with application of methodology of formalized analysis of lexical semantics. The object of research is the 
English terms of geology with the explanation of their special and common language meanings taken from lexicographical sources. The investigation is aimed at determining special terminological meanings of the analysed words in the connection with their common language semantics. Application of componential analysis helped to single out semantic components (semes) from common language and terminological meanings of lexical units. Methodology of formalized analysis enabled us to construct the matrix of semantic space of English terminology of geology according to the principle of rank arrangement of the components of meaning. The matrix provided the possibility of distinguishing three groups of terms (lexical units with wide semantics, lexical units with average degree of semantics and lexical units with narrow semantics) and three groups of semes (according to the degree of their functionality). The present research helped to define different connections of terminological lexis inside geology terminological system, with terms of other domains, common language lexical units and revealed the possibilities of further semantic study of terminological lexis.

\section{REFERENCES}

1. Aitchison Jane. Linguistics. - London: Hodder and Stoughton, 2003. - 240p.

2. Cruise D.A. Monosemy vs. polysemy: Linguistics. - Cambridge, 1992. $-599 \mathrm{p}$.

3. Enesi M. Strati K. Contemporary methods of semantic studies and their impact in translation // Interdisiplinary Journal of Research and Development, Vol. 4. № 3. 2017. - P. 117-126.

4. Goodenough W.H. Componential Analysis and the Study of Meaning. Language 32(1): 1956. - P. 195-216.

5. Leech G. Semantics. - London: Penguin Books, 1975. - 386p.

6. Saeed, John. Semantics. - United Kingdom: Wiley Blackwell, 2009. - 44 3p.

7. Алієва О. Спільний інваріантний компонент: формування семантичної та концептуальної структури терміна // Сучасні дослідження з іноземної філології. Вип.13, 2015. - С. 269-273.

8. Арнольд И.В. Семантическая структура слова в современном английском языке и методика ее исследования. - Л.: Просвещение, 1966. - $192 \mathrm{c}$.

9. Іваницький Р.В. Лексикографічні аспекти нормалізації термінів (на матеріалі німецьких, англійських, українських та російських термінологічних одиниць): Автореферат дис. ... канд.філол. наук. Львів, 1995. - 20 с. 
10. Кузнецова Е.В. Лексикология русского языка. - М.: Высшая школа, 1989. - $216 \mathrm{c.}$

11. Пещак М.М. Специфіка формальних ознак лексикографічної обробки слова // Формалізовані основи семантичної класифікації лексики. - Київ: Наукова думка, 1982. - С. 10-55.

12. Сорока Т.В. Семантика найбільш багатозначних англійських аксіономерів // Сучасні дослідження 3 іноземної філології. Збірник наукових праць. - Ужгород. Вип 12. 2014. - С. 189-200.

13. Фабіан М.П. Етикетна лексика в українській, англійській та угорській мовах. - Ужгород: Інформаційно-видавниче агентство «IBA», 1998. - $256 \mathrm{c}$.

14. Харитончик 3.А. Лексикология английского языка. - Минск: Вышейшая школа, 1992. - 229 с.

\section{SOURCES}

15. Longman Dictionary of Contemporary English. - Longman Group Ltd, 2000.

16. McGraw-Hill Dictionary of Earth Science. - New York. $2^{\text {nd }}$ edition, 2003 [Electronic resource]: yunus.hacettepe.edu.tr

17. McGraw-Hill Dictionary of Geology and Mineralogy. - New York. $2^{\text {nd }}$ edition, 2003 [Electronic resource]: https://www.academia.edu/ 10260338/

Information about the author: Rohach L. V.,

Candidate of Philological Sciences, Associate Professor at the Department of English Philology,

Uzhhorod National University 14, Universytetska str., Uzhhorod, 88000, Ukraine 